\title{
STUDY OF CARBONATION DURABILITY OF SEVERAL ETTRINGITE-ENRICHED PASTES
}

\author{
BAO CHEN ${ }^{1,2}$, MATTHIEU HORGNIES ${ }^{2}$, VINCENT MORIN ${ }^{2}$, MOUNA BOUMAAZA $^{2}$, BRUNO HUET $^{2}$, \\ EDOUARD GENGEMBRE ${ }^{2}$, ISABELLE BACO ${ }^{2}$, KEVYN JOHANNES $^{1} \&$ FREDERIC KUZNIK $^{1}$ \\ ${ }^{1}$ Université de Lyon, France \\ ${ }^{2}$ LafargeHolcim R\&D, France
}

\begin{abstract}
Recent reported materials of high energy density for thermochemical heat storage are mostly inorganic rare elements salts, such as $\mathrm{SrBr}_{2}$ and $\mathrm{LaCl}_{3}$. However, their wide use may be hindered due to the high material cost. An affordable cement-based compound, named ettringite, of which energy density $\left(\sim 500 \mathrm{kWh} / \mathrm{m}^{3}\right)$ is comparable, and even higher, than rare elements salts and therefore attracts people's sight. As an alkaline phase in hydrated cement pastes, ettringite could be carbonated by $\mathrm{CO}_{2}$ in the air. The change of this mineral structure upon carbonation could reduce its capacity to store energy. This phenomenon is known to be unstoppable until there is a complete depletion of reactants. Consequently, it is necessary to investigate the carbonation rate of ettringite-based materials for energy storage. In the present work, a large range of characterization methods - such as optical microscopy analysis, mercury intrusion porosimetry (MIP), X-ray fluorescence (XRF), X-ray diffraction (XRD), Thermogravimetric analysis (TGA) - have been carried out to analyse phase structure and phase assemblage. Three series of cement pastes containing different contents of ettringite were firstly prepared. Then, crushed samples of a size of $1-2 \mathrm{~mm}$ were exposed to an accelerated carbonation environment (composed of $1 \% \mathrm{CO}_{2}$ by volume, and $90 \%$ relative humidity $(\mathrm{RH})$ at $20^{\circ} \mathrm{C}$ and ambient pressure) for different durations. The results have highlighted that the carbonation of ettringite-based granules under set conditions went very fast. The XRD patterns confirmed that the calcium carbonates were vaterite and aragonite accompanied with gypsum. Moreover, a bigger content of ettringite seemed to yield a higher carbonation resistance and a less foamy structure.
\end{abstract}

Keywords: carbonation, durability, ettringite-based material, TGA, XRD, energy storage.

\section{INTRODUCTION}

Nowadays, the primary energy consumption in building or industry sector is more significant than petrol depletion in transport sector all over the world. Besides, a local/individual secondary energy supply system is assumed to be efficient to reduce the operating burden on national grids during heating consumption peaks in winter. Therefore, thermal energy storage systems are developed to reduce the load peak of consumption of electricity. Recent investigations [1]-[5] on a thermochemical material named ettringite proposed a good solution to reduce the cost of construction of backup system. The energy density can reach up to $500 \mathrm{kWh} / \mathrm{m}^{3}$ for a working temperature as low as $60^{\circ} \mathrm{C}$, which guarantees its adaption to most renewable heat sources [1]. However, as an alkaline material from hydrated cement paste, its reactivity with $\mathrm{CO}_{2}$ in air is unavoidable in heat storage systems. Indeed, carbonation can affect the crystal structure of ettringite to several simple chemical compounds thereby losing its capacity to store heat.

Robl et al. [6] reported that dry ettringite samples did not react significantly with $\mathrm{CO}_{2}$ while humid ettringite reacted rapidly. Pajares et al. [7] reported the harmful effect of carbonate ions on ettringite's stability, from $\mathrm{CaCO}_{3}$ and $\mathrm{MgCO}_{3}$ silica gel saturated solution, at ambient temperature. However, the presence of $\mathrm{Ca}(\mathrm{OH})_{2}$ could evidently delay the carbonation of ettringite, since the capacity of Portlandite $\left(\mathrm{Ca}(\mathrm{OH})_{2}\right)$ to buffer the carbonation reaction prevents significant deterioration of the remaining phases. The same phenomenon caused by carbonate ions at different temperatures was equally investigated [8]. 
Grounds et al. [9] described the carbonation rate of a synthetic ettringite powder in atmospheric $\mathrm{CO}_{2}$. The carbonation reaction was inferred by X-ray diffraction (XRD) as:

$$
3 \mathrm{CaO} \cdot \mathrm{Al}_{2} \mathrm{O}_{3} \cdot 3 \mathrm{CaSO}_{4} \cdot 32 \mathrm{H}_{2} \mathrm{O}+3 \mathrm{CO}_{2} \rightarrow 3 \mathrm{CaSO}_{4} \cdot 2 \mathrm{H}_{2} \mathrm{O}+3 \mathrm{CaCO}_{3}+2 \mathrm{Al}(\mathrm{OH})_{3}+23 \mathrm{H}_{2} \mathrm{O}
$$

Nishikawa et al. [10] confirmed this carbonation reaction of ettringite powder at high relative humidity $(\mathrm{RH})$. Detailed works by Chen et al. [11] stated that the increase of $\mathrm{CO}_{2}$ pressure, water vapour and temperature could accelerate the carbonation of ettringite. Zhou and Glasser [12] also reported the acceleration of carbonation with both increasing relative humidity and temperature via carbonation experiments on ettringite powder and pellets ( $2.5 \mathrm{~mm}$ thick, pressed to about $80 \%$ theoretical density). Differing from powder cases, AFm phase was detected due to a possible condensation of water in the pores and inter-crystalline space in pellet samples. Ndiaye et al. [4] demonstrated that the carbonation of ettringite in CSA paste powder yielded to bassanite $\left(\mathrm{CaSO}_{4} \cdot 0.5 \mathrm{H}_{2} \mathrm{O}\right)$ instead of gypsum accompanied by aragonite and vaterite as $\mathrm{CaCO}_{3}$ at $65 \% \mathrm{RH}$.

Most previous research about the carbonation of ettringite were based on synthetic powders which may cause agglomeration during energy storage processes. Consequently, our investigations were carried out on grains $(1-2 \mathrm{~mm})$ of hydrated pastes that were confirmed to contain high quantities of ettringite. In this paper, we detail our carbonation experiments surveying accelerated carbonation $\left(1 \mathrm{vol} . \% \mathrm{CO}_{2}\right)$ on three mixtures from Belite-Calcium Sulfoaluminate-Ferrite Cement (BCSAF), Calcium Aluminate Cement (CAC) and Ordinary Portland Cement (OPC) via main methods like optical microscopy, mercury intrusion porosimetry (MIP), X-ray fluorescence (XRF), X-ray diffraction (XRD) and Thermogravimetric analysis (TGA). Meanwhile, the evolution of components and according quantity as a function of carbonation time is discussed.

\section{MATERIALS AND METHODS}

\subsection{Raw materials}

The tested cement pastes were firstly characterized by XRF and XRD to determine the initial existing phases and quantities. The results are demonstrated in Table 1. The sums of different columns inferior to 100 are related to unlisted minor phases.

\subsection{Preparation of the tested samples}

Three binders used result in around $565 \mathrm{~g}$ anhydrous mixture respectively from pure BCSAF (abbreviated as BCSAF), 80\% CAC and 20\% OPC (abbreviated as C80P20), and 60\% CAC and $40 \%$ OPC (abbreviated as $\mathrm{C} 60 \mathrm{P} 40$ ). Then the mixtures were particularly hydrated by demineralized water of $1.1 \times$ anhydrous mixture, a little of Chryso ${ }^{\circledR}$ Premia $180(0.05$ wt. \% of binder) and Kelco-Crete ${ }^{\circledR}$ DG-F (0.1 wt. \% of water). After a correct agitation by a mixer machine for $10 \mathrm{~min}$ at $1000 \mathrm{r} / \mathrm{min}$, the pastes were sealed in polystyrene moulds $(4 \times 4 \times$ $16 \mathrm{~cm}$ ) by a glass plate for $24 \mathrm{~h}$. At $1 \mathrm{~d}$, harden pastes were then stored in sealed plastic bags at about $22^{\circ} \mathrm{C}$ for $27 \mathrm{~d}$ to avoid carbonation. At last, the prims were crushed down to $1-2 \mathrm{~mm}$ grains. Meanwhile, several pieces of harden pastes were characterized by MIP (Autopore IV of Micromeritics, USA). The mean size of grains was analysed by optical microscopy (Stereoscopic magnifier STEMI SV 11). 
Table 1: Chemical and mineralogical composition of cements by XRF and $\mathrm{XRD}^{1}$.

\begin{tabular}{|c|c|c|c|c|c|c|c|}
\hline & OPC & CAC & BCSAF & & OPC & $\mathrm{CAC}$ & BCSAF \\
\hline $\mathrm{SiO}_{2}$ & 20.3 & 1.9 & 12.4 & $\mathrm{C}_{3} \mathrm{~S}$ & 70.7 & - & - \\
\hline $\mathrm{Al}_{2} \mathrm{O}_{3}$ & 5.4 & 23.4 & 16.9 & $\mathrm{C}_{2} \mathrm{~S}$ & 7.3 & - & 30.9 \\
\hline $\mathrm{Fe}_{2} \mathrm{O}_{3}$ & 2.5 & 0.5 & 6.3 & $\mathrm{C}_{4} \mathrm{AF}$ & 7.4 & - & 16.4 \\
\hline $\mathrm{CaO}$ & 64.2 & 43.2 & 47.3 & $\mathrm{C}_{3} \mathrm{~A}$ & 8.5 & - & - \\
\hline $\mathrm{MgO}$ & 1.2 & 0.3 & 1.4 & $\mathrm{C} \overline{\mathrm{S}} \mathrm{H}_{0.5}$ & 3.2 & - & 3.7 \\
\hline $\mathrm{K}_{2} \mathrm{O}$ & 0.2 & 0.1 & 0.7 & $\mathrm{C} \overline{\mathrm{S}} \mathrm{H}_{2}$ & 2.6 & - & 1.2 \\
\hline $\mathrm{Na}_{2} \mathrm{O}$ & 0.2 & 0.1 & 0.1 & $\mathrm{C} \overline{\mathrm{S}}$ & - & 52.5 & 10.7 \\
\hline $\mathrm{SO}_{3}$ & 3.3 & 28.8 & 9.9 & $\mathrm{C}_{12} \mathrm{~A}_{7}$ & - & 3.5 & - \\
\hline $\mathrm{TiO}_{2}$ & 0.2 & 1.1 & 0.9 & $\mathrm{C}_{4} \mathrm{~A}_{3} \overline{\mathrm{S}}$ & - & - & 31.1 \\
\hline $\mathrm{Mn}_{2} \mathrm{O}_{3}$ & 0.1 & $<0.1$ & 0.1 & $\mathrm{MgO}$ & - & - & 0.5 \\
\hline $\mathrm{P}_{2} \mathrm{O}_{5}$ & 0.3 & 0.1 & 0.1 & Fero-perovskite & - & - & 3.6 \\
\hline $\mathrm{Cr}_{2} \mathrm{O}_{3}$ & $<0.1$ & $<0.1$ & $<0.1$ & Ettringite & - & - & 1.5 \\
\hline $\mathrm{ZrO}_{2}$ & $<0.1$ & $<0.1$ & $<0.1$ & Monosulfoaluminate & - & - & 0.3 \\
\hline $\mathrm{SrO}_{2}$ & 0.1 & $<0.1$ & 0.1 & Amorphous phase & - & 44.0 & - \\
\hline Total & 98.2 & 99.9 & 96.4 & & 99.7 & 100.0 & 99.9 \\
\hline
\end{tabular}

${ }^{1}$ Cement notions: $\mathrm{A}=$ Alumina $\left(\mathrm{Al}_{2} \mathrm{O}_{3}\right), \mathrm{C}=\mathrm{Lime}(\mathrm{CaO}), \mathrm{H}=$ Water $\left(\mathrm{H}_{2} \mathrm{O}\right), \mathrm{F}=$ Iron oxide $\left(\mathrm{Fe}_{2} \mathrm{O}_{3}\right), \mathrm{S}=$ Silica $\left(\mathrm{SiO}_{2}\right), \overline{\mathrm{S}}=$ Sulphur trioxide $\left(\mathrm{SO}_{3}\right)$.

\subsection{Accelerated carbonation and solid analysis}

About $4 \mathrm{~g}$ grains of each carbonation date were evenly paved in an aluminium dish of $8 \mathrm{~cm}$. The samples carbonated in a $\mathrm{CO}_{2}$ climate chamber (Pharma 600 of Weisstechnik ${ }^{\circledR}$ ) where $\mathrm{RH}, \mathrm{CO}_{2}$ concentration and temperature were maintained at $90 \%, 1$ vol. $\%$ and $20^{\circ} \mathrm{C}$ for 0 , $2 \mathrm{~h}, 6 \mathrm{~h}, 1 \mathrm{~d}, 11 \mathrm{~d}$ and $28 \mathrm{~d}$. For each carbonation period, the samples were analysed by XRD (Philips / PANalytical X'Pert Pro-MPD coupled with X'Celerator detector of incident CuK $\alpha$ radiation beam by $40 \mathrm{kV}$ and $40 \mathrm{~mA}, 2 \theta=\left[5-65^{\circ}\right]$ ) and TGA (Metller TGA-DSC $3^{+}$, from 30 to $1000^{\circ} \mathrm{C}$ at $10^{\circ} \mathrm{C} / \mathrm{min}$ under protection of $20 \mathrm{~mL} / \mathrm{min}$ nitrogen) to determine carbonation products and quantity of absorbed $\mathrm{CO}_{2}$.

\subsection{TGA and XRD data processing}

The temperature of releasing $\mathrm{CO}_{2}$ is supposed to be in the range $550-1000^{\circ} \mathrm{C}$. The maximum of bonded $\mathrm{CO}_{2}$ was called the $\mathrm{CO}_{2}$ binding capacity. For the variation of mass caused by water loss during carbonation, seeing eqn (1), the indicator of carbonation was defined as:

$$
I=\frac{m_{\mathrm{CO} 2}}{m_{\text {cement }}}=\frac{m_{\text {initiale } T G A^{*}\left(a_{550}{ }^{\circ} \mathrm{C}-a_{1000}{ }^{\circ} \mathrm{C}\right.}}{m_{\text {initiale } T G A^{*}} a_{1000}{ }^{\circ} \mathrm{C}},
$$

where $I$ is the carbonation degree, $m$ is the weight from TGA and $a$ is the weight percentage from TGA.

Carbonation was hard to avoid during preparation of samples. The absolute carbonation degree for accelerated carbonation was calculated as the following:

$$
I_{r}=I_{t}-I_{0}
$$


where $I_{t}$ is the carbonation degree at time t, $I_{0}$ is the initial carbonation degree before accelerated carbonation.

The analysis results of XRD were equally recalculated with TGA results, seeing eqn (4)

$$
X=\frac{X_{X R D^{*} m_{\text {initial TGA }}}}{m_{\text {cement }}}=\frac{X_{X R D^{*} m_{\text {initial TGA }}}}{m_{\text {initial } T G A^{*}} a_{1000^{\circ} \mathrm{C}}}
$$

where $X$ is the recalculated percentage of components, $X_{X R D}$ the original weight percentage from XRD, $m$ and $a$ are respectively the weight and weight percentage in TGA.

\subsection{Maximum $\mathrm{CO}_{2}$ binding capacity}

According to the XRF results, the maximum carbonation degree $\left(\mathrm{CO}_{2}\right.$ binding capacity) of cement paste could be computed using eqn (5) under the following assumptions:

$>\mathrm{CaSO}_{4}$ is the only final formula of sulphates;

$>\mathrm{CaO}$ and $\mathrm{MgO}$ are the main phases to be carbonated

$$
I_{\text {max }}=\sum \frac{m_{\mathrm{CO} 2}}{m_{\text {mixture }}}=\sum \frac{\left(\frac{a_{\mathrm{CaO}}}{M(\mathrm{CaO})}+\frac{a_{M g O}}{M(\mathrm{MgO})}-\frac{a_{\mathrm{SO} 3}}{M\left(\mathrm{SO}_{3}\right)}\right) * m_{\text {cement }} * M\left(\mathrm{CO}_{2}\right)}{m_{\text {anhydrous solid }}},
$$

where $I$ is the carbonation degree, $m$ is the weight $(\mathrm{g}), a$ is the percentage and $M$ is molar mass of compounds $(\mathrm{g} / \mathrm{mol})$. Along with eqn (5), the theoretical $\mathrm{CO}_{2}$ binding capacities are around $25 \%$ for C80P20, $31 \%$ for C60P40 and 33\% for BCSAF.

\section{RESULTS AND DISCUSSIONS}

\subsection{Characterizations of reference binders}

The grains from different mixtures generally range in $1-2 \mathrm{~mm}$ by sieving. More precisely, the mean sizes are $1.04 \mathrm{~mm}, 0.98 \mathrm{~mm}$ and $1.13 \mathrm{~mm}$ for C80P20 C60P40 and BCSAF respectively given by optical microscopy (Fig. 1).

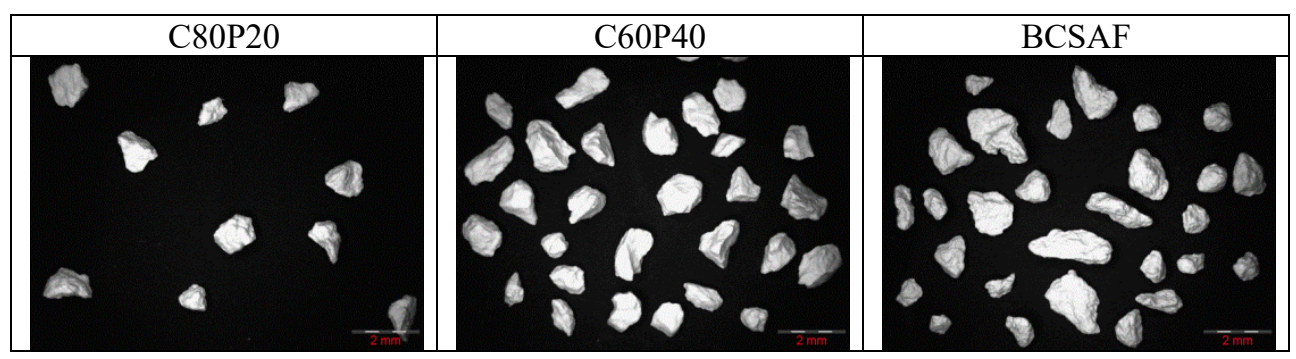

Figure 1: Optical microscopy analysis of grain size $(1-2 \mathrm{~mm})$ for three binders' pates.

The grains of three hydrated binders were also characterized by MIP to determine their porosity and pore size distribution before exposure to carbonation. As expected, due to their high water to binder ratio, results from Fig. 2 show high porosities of the tested samples (above 30\%). Generally, they are in the order of BCSAF $(\sim 53 \%)>$ C60P40 $(\sim 38 \%)>$ C $80 \mathrm{P} 20$ $(\sim 34 \%)$. This order is in contrast with their ettringite contents indicated by XRD. Actually, C80P20 contains $\sim 73 \%$ ettringite while $\sim 65 \%$ for C60P40 and only about $40 \%$ for BCSAF. 


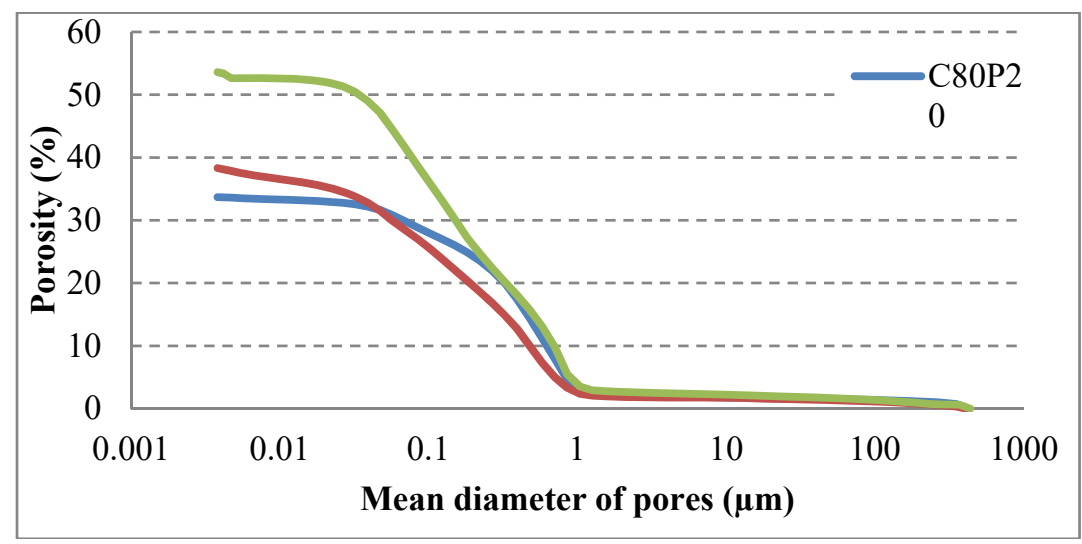

Figure 2: Porosity of the three hydrated binders by MIP.

Therefore, the growth of a big quantity of ettringite crystals into pores may reduce the quantity and size of pores. For the three hydrated binders, most pores range between $0.03-1 \mu \mathrm{m}$ and they get less porosity from micro-pores with a diameter inferior to $0.01 \mu \mathrm{m}$ or big pores with a diameter superior to $1 \mu \mathrm{m}$. Hydrated BCSAF is the only one with significant pore volume for pore diameter below $0.1 \mu \mathrm{m}$. These pores behave as water containers during carbonation.

\subsection{Evolution of hydrated binder grains upon accelerated carbonation}

At each set date of carbonation, the corresponding samples were analysed by TGA and XRD techniques. The error of thermal analysis is estimated about $1 \%$. The TGA results are demonstrated in Fig. 3. The "turning points" of curves for C60P40 and BCSAF are at $2 \mathrm{~h}$ while at $6 \mathrm{~h}$ for C80P20. This trend may indicate that the carbonation of particles could be separated to two periods: before turning point, carbonation is dominated by chemical reaction at surface of grains; after a turning point, carbonation is a diffusion-controlled process.



Figure 3: Carbonation degrees of three binders' grains (1-2mm) by TGA at different carbonation dates. 
Among the three pastes, BCSAF seems to be the least resistant against carbonation while C80P20 is the most resistant. However, the difference between C60P40 and BCSAF is not high, which may be explained by their $\mathrm{CO}_{2}$ binding capacities and porosities. Because of a higher porosity of BCSAF paste comparing to $\mathrm{C} 60 \mathrm{P} 40$, the diffusion of $\mathrm{CO}_{2}$ is supposed to be faster in BCSAF than in C60P40. However, this advantage may not be so significant due to that both of the grains have large pores and entry diameter $(\sim 1 \mu \mathrm{m})$ resulting in less influence led by $\mathrm{CO}_{2}$ diffusion. Compared to BCSAF and C60P40, not only the carbonation rate but also the carbonation degree of C80P20 is less significant. This result comes out under both effects from relatively small porosity and $\mathrm{CO}_{2}$ binding capacity. Typically, at $1 \mathrm{~d}$, the absolute carbonation degree of C80P20, C60P40 and BCSAF are $4.2 \%, 14.1 \%$ and $11.6 \%$, respectively reaches $16.8 \%, 45.5 \%$ and $35.2 \%$ of theoretical $\mathrm{CO}_{2}$ binding capacities.

Similarly to TGA data, the change of ettringite content in C80P20 grains during first $6 \mathrm{~h}$ is low (Fig. 4). The little change of $\mathrm{CaCO}_{3}$ quantity ( $\mathrm{V}+\mathrm{A}$ in Fig. 4) during first $6 \mathrm{~h}$ may suggest the formation of transition product containing $\mathrm{CO}_{2}$. Then the carbonation of major ettringite before $11 \mathrm{~d}$ increases significantly the quantity of vaterite and aragonite, which corresponds to a large increase of carbonation degree in TGA curves from $6 \mathrm{~h}$ to $11 \mathrm{~d}$. After $11 \mathrm{~d}$, no ettringite exists yielding to no increase of gypsum content. The growth of $\mathrm{CaCO}_{3}$ comes from the carbonation of a part of other hydrates in the grains. Here, the main $\mathrm{CaCO}_{3}$ formed by carbonation of ettringite is equally confirmed as vaterite and aragonite since that hardly any calcite forms during whole process. Meanwhile amorphous aluminium hydroxyl is also detected during the carbonation of ettringite.

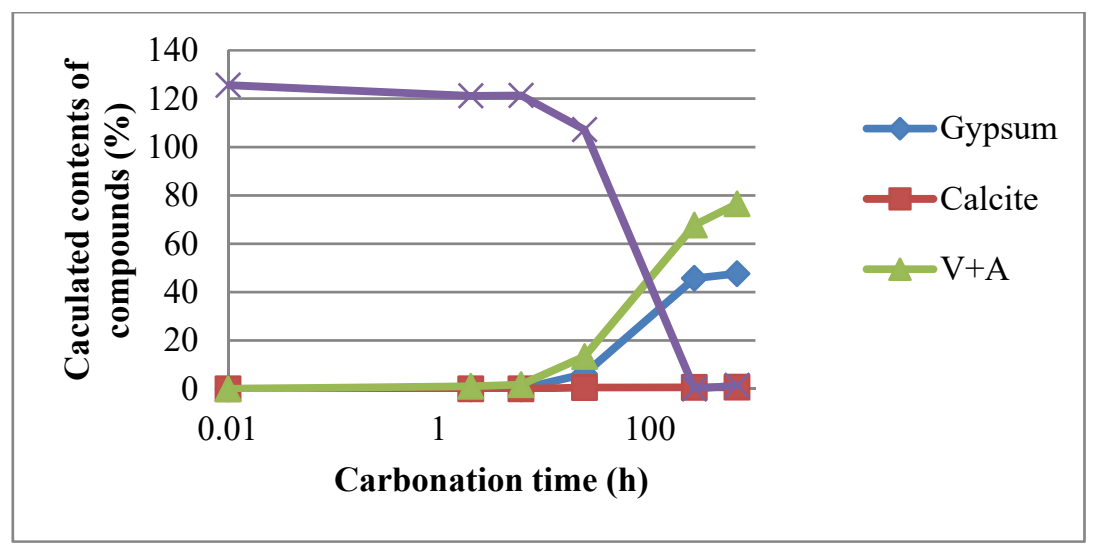

Figure 4: Mineralogical evolution and calculated contents of compounds by XRD for C80P20 1-2mm grains at different dates of carbonation. $\mathrm{V}+\mathrm{A}$ presents the total content of vaterite and aragonite.

As for C60P40 (Fig. 5), the mechanism of carbonation seems to be different. First, a new hydrate containing $\mathrm{CO}_{3}{ }^{2-}$ named calcium hemicarboaluminate hydrate $(\mathrm{Hc})$ exists before carbonation experiment, eqn (6). The existence of this hydrate proves that some carbonation occurred during the preparation of grains. Monosulfoaluminate was equally found before experiments. At the very beginning of carbonation (before $6 \mathrm{~h}$ ), a remarkable amount of ettringite in $\mathrm{C} 60 \mathrm{P} 40$ is decomposed, firstly to monosulfoaluminate. On the one hand, this decomposition of ettringite may occur under $\mathrm{CO}_{2}$ influence along with releasing of sulphates and calcium ions into pore solution. On the other hand, unreacted anhydrous phases can also 
react with ettringite to form monosulfoaluminate. Further, $\mathrm{CO}_{3}{ }^{2-}$ produced by dissolved $\mathrm{CO}_{2}$ in pore solution bonds calcium ions to form $\mathrm{CaCO}_{3}$. After $6 \mathrm{~h}$ of carbonation, the $\mathrm{pH}$ of pore solution possibly reduces significantly which makes ettringite, monosulfate and $\mathrm{Hc}$ carbonated to $\mathrm{CaCO}_{3}$ directly. At $24 \mathrm{~h}$, more than half of ettringite is carbonated while no monosulfate remains. This result possibly indicates that monosulfate is more reactive to $\mathrm{CO}_{2}$ than ettringite. The rate of consuming ettringite is about 3 times higher for $\mathrm{C} 60 \mathrm{P} 40$ than C80P20 at $24 \mathrm{~h}$ given by XRD. After the complete depletion of ettringite at $11 \mathrm{~d}$, the increased quantity of vaterite and aragonite comes from the carbonation of other hydrates in the C60P40 grains like strätlingite and katoite.

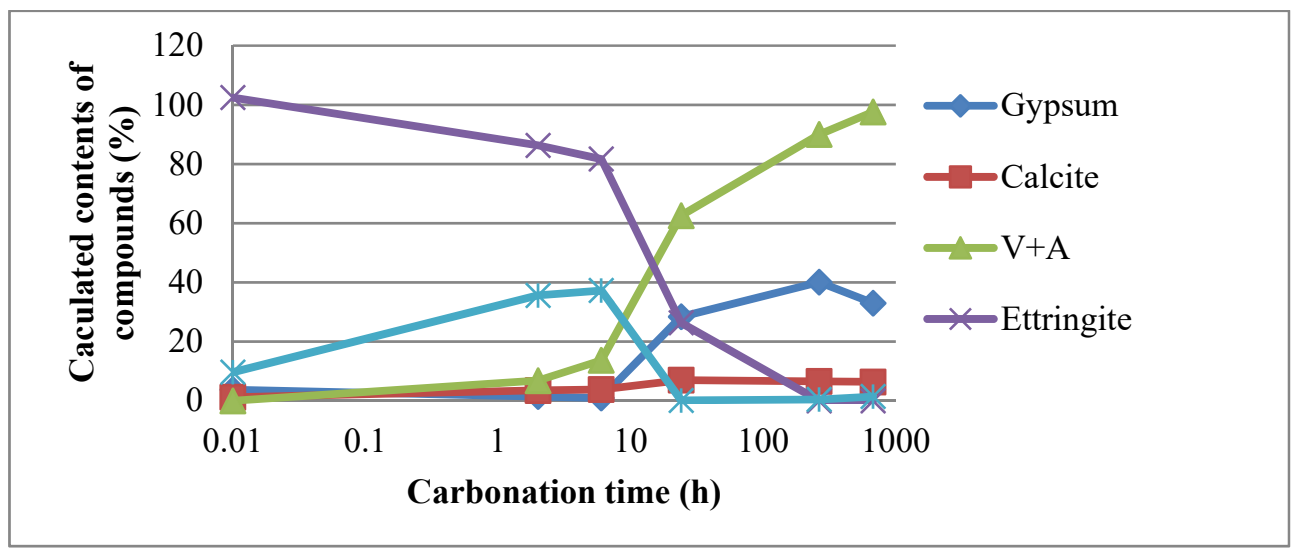

Figure 5: Mineralogical evolution and calculated content of compounds by XRD for C60P40 $1-2 \mathrm{~mm}$ grains at different carbonation periods. $\mathrm{V}+\mathrm{A}$ : the total content of vaterite and aragonite.

$$
\begin{aligned}
& 3 \mathrm{C}_{3} \mathrm{~A}+3 \mathrm{CaSO}_{4}+2 \mathrm{Ca}(\mathrm{OH})_{2}+\mathrm{CO}_{2}+55 \mathrm{H}_{2} \mathrm{O} \rightarrow 3 \mathrm{CaO} \cdot \mathrm{Al}_{2} \mathrm{O}_{3} \cdot 3 \mathrm{CaSO}_{4} \cdot 32 \mathrm{H}_{2} \mathrm{O} \\
& +23 \mathrm{CaO} \cdot \mathrm{Al}_{2} \mathrm{O}_{3} \cdot 1 / 2 \mathrm{CaCO}_{3} \cdot 1 / 2 \mathrm{Ca}(\mathrm{OH})_{2} \cdot 11.5 \mathrm{H}_{2} \mathrm{O}
\end{aligned}
$$

Being consistent with TGA results, BCSAF demonstrates the highest $\mathrm{CaCO}_{3}$ content in grains than other two other mixtures at $28 \mathrm{~d}$ in XRD patterns (Fig. 6). During first $2 \mathrm{~h}$ of carbonation, ettringite is scarcely carbonated. Therefore, the rise of $\mathrm{CaCO}_{3}$ may be owing to the carbonation of amorphous hydrate $\mathrm{CSH}$. Then ettringite becomes to be the major phase carbonated. Because of owning relative low quantity of ettringite in comparison with C80P20 and $\mathrm{C} 60 \mathrm{P} 40$, almost all ettringite react at $24 \mathrm{~h}$. Similarly to C80P20, once ettringite is totally consumed after $11 \mathrm{~d}$, the increase of gypsum is stopped considering measurement error. After that, the increase of $\mathrm{CaCO}_{3}$ is mainly related to the carbonation of other hydrates like strätlingite and katoite without producing any sulphate bearing minerals. 


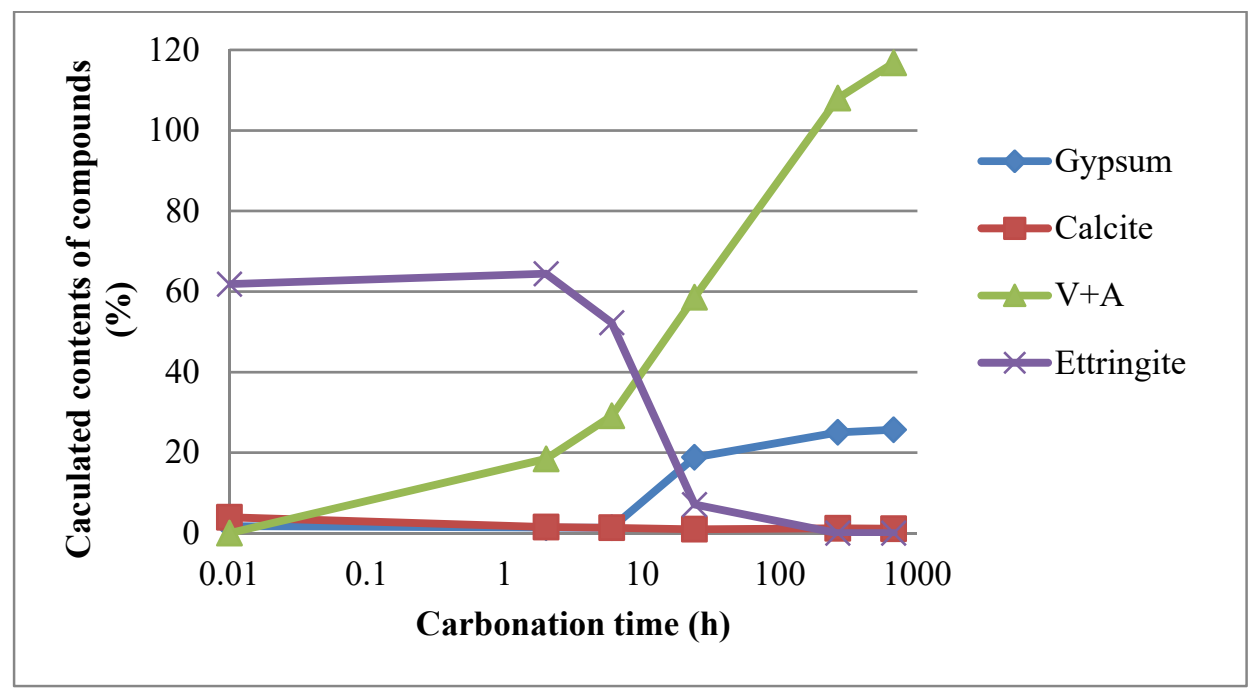

Figure 6: Mineralogical evolution and calculated contents of compounds by XRD for BCSAF $1-2 \mathrm{~mm}$ grains at different dates of carbonation. $\mathrm{V}+\mathrm{A}$ : the total content of vaterite and aragonite.

\section{CONCLUSIONS}

Accelerated carbonation tests at high relative humidity, carried out on 1-2mm grains of three materials containing different ettringite contents were investigated. The carbonation degree and evolution of carbonation products were demonstrated by analysing TGA and XRD data. At the same time, the changes of phase assemblage and their carbonation resistance were discussed. Main outcomes of this investigation are listed as follow:

- $\mathrm{C} 80 \mathrm{P} 20$ has a better carbonation resistance than the other two ettringite enriched materials. Especially at $1 \mathrm{~d}$, the absolute carbonation degree of C $80 \mathrm{P} 20$ only reaches $16.8 \%$ of according theoretical $\mathrm{CO} 2$ binding capacity, while it is at least two times more for the other two binders.

- The carbonation products of ettringite at $90 \%$ RH are principally gypsum, amorphous aluminium hydroxyl, vaterite and aragonite as calcium carbonates that were found in XRD analysis.

- At the very beginning of accelerated carbonation for $\mathrm{C} 60 \mathrm{P} 40$, the formation of monosulfoaluminate from ettringite has been observed. During the carbonation process, monosulfate shows more vulnerable to $\mathrm{CO}_{2}$ than ettringite. Moreover, some hydrates like strätlingite, katoite and tobermorite, prove a better resistance against $\mathrm{CO}_{2}$ than ettringite: they react with $\mathrm{CO}_{2}$ after ettringite.

- The turning points of carbonation degree of three binders possibly suggest two steps of carbonation for the grains of three binders: a surface reaction stage and $\mathrm{CO}_{2}$ diffusion controlled process.

\section{ACKNOWLEDGEMENTS}

We express our appreciation to LafargeHolcim R\&D and Association Nationale de la Recherche et de la Technologie (ANRT) of France for the funding of this research. 


\section{REFERENCES}

[1] Chen, B., Kuznik, F., Horgnies, M., Johannes, K., Morin, M. \& Gengembre E., Physicochemical properties of ettringite/meta-ettringite for thermal energy storage: Review. Solar Energy Materials and Solar Cells, 193, pp. 320-334, 2019.

[2] Baquerizo, L.G., Matschei, T. \& Scrivener, K.L., Impact of water activity on the stability of ettringite. Cement and Concrete Research, 79, pp. 31-44, 2016.

[3] Ndiaye, K., Ginestet, S. \& Cyr, M., Thermal energy storage based on cementitious materials: A review. AIMS Energy, 6(1), pp. 97-120, 2018.

[4] Ndiaye, K., Cyr, M. \& Ginestet, S., Durability and stability of an ettringite-based material for thermal energy storage at low temperature. Cement and Concrete Research, 99, pp. 106-115, 2017.

[5] Kaufmann, J., Winnefeld, F. \& Lothenbach, B., Stability of ettringite in CSA cement at elevated temperatures. Advances in Cement Research, 28(4), pp. 251-261, 2016.

[6] Robl, T.L., Graham, U.M. \& Taulbee, D.N., The effect of carbonation reactions on the long term stability of products made from dry FGD materials. Preprints of Papers, American Chemical Society, Division of Fuel Chemistry. United States, 1996. Available at: https://www.osti.gov/servlets/purl/430280.

[7] Pajares, I., Martínez-Ramírez, S. \& Blanco-Varela, M.T., Evolution of ettringite in presence of carbonate, and silicate ions. Cement and Concrete Composites, 25(8), pp. 861-865, 2003.

[8] Carmona-Quiroga, P.M. \& Blanco-Varela, M.T., Ettringite decomposition in the presence of barium carbonate. Cement and Concrete Research, 52, pp. 140-148, 2013.

[9] Grounds, T., Midgley, H.G. \& Novell, D.V., Carbonation of ettringite by atmospheric carbon dioxide. Thermochimica Acta, 135, pp. 347-352, 1988.

[10] Nishikawa, T., Suzuki, K., Ito, S., Sato, K. \& Takebe, T., Decomposition of synthesized ettringite by carbonation. Cement and Concrete Research, 22(1), pp. 6$14,1992$.

[11] Chen, X., Zou, R. \& Chen, X., Kinetic study of ettringite carbonation reaction. Cement and Concrete Research, 24(7), pp. 1383-1389, 1994.

[12] Zhou, Q. \& Glasser, F.P., Kinetics and mechanism of the carbonation of ettringite. Advances in Cement Research, 12(3), pp. 131-136, 2000. 